\title{
新規シリカ基材に製膜した高速ガス選択透過 MFIゼオライト膜
}

\author{
野村幹弘 1)*・杉山雄飛 1）・大浦琴音1）・池田 歩1）・松山絵美 1）・ \\ 俵山博匡 2) ・桑原一也 2) \\ 1）芝浦工業大学 工学部 応用化学科 \\ 干 135-8548 東京都江東区豊洲 3-7-5 \\ 2）住友電気工業株式会社 光通信研究所 \\ 干 244-8588 横浜市栄区田谷町 1
}

\section{High Gas Permselective MFI Zeolite Membranes Prepared on Novel Silica Substrates}

\author{
Mikihiro Nomura ${ }^{1)}$, Yuto Sugiyama ${ }^{1)}$, Kotone Oura ${ }^{1)}$, Ayumi Ikeda ${ }^{1)}$, \\ Emi Matsuyama ${ }^{1)}$, Hiromasa Tawarayama ${ }^{2)}$, and Kazuya Kuwahara ${ }^{2)}$
}

1) Shibaura Institute of Technology, Department of Applied Chemistry 3-7-5, Toyosu, Koto-ku, Tokyo 135-8548, Japan

2) Sumitomo Electric Industries, Ltd. Optical Communications R\&D Labs 1, Taya-cho, Sakae-ku, Yokohama 244-8588, Japan

MFI membranes with high gas permselectivities were successfully prepared on a novel porous silica substrate. Procedures for coating of MFI seed crystals are important due to $\zeta$-potential difference between the silica substrates and the seed crystals. Dense MFI membranes were obtained from the seed slurry of $\mathrm{pH} 2$, because the isoelectric $\mathrm{pH}$ of silica is 2 . MFI membranes were crystalized at $180^{\circ} \mathrm{C}$ for $16 \mathrm{~h}$. The parent gel compositions were $\mathrm{SiO}_{2}$ : TPABr: $\mathrm{Na}_{2} \mathrm{O}: \mathrm{H}_{2} \mathrm{O}=1: 0.2: 0.01 \sim 0.6: 150 \sim 600(\mathrm{~mol} / \mathrm{mol})$. Single gas permeation tests were performed by using $\mathrm{N}_{2}, \mathrm{SF}_{6}, \mathrm{C}_{3} \mathrm{H}_{6}$ and $\mathrm{C}_{3} \mathrm{H}_{8}$ at room temperature. $\mathrm{N}_{2}$ permeance was $3.0 \times 10^{-6} \mathrm{~mol} \mathrm{~m}^{-2} \mathrm{~s}^{-1} \mathrm{~Pa}^{-1}$ with high $\mathrm{N}_{2} / \mathrm{SF}_{6}$ permeance ratio of 108 through the membrane. This is one of the best results among the previously reported MFI membranes. This membrane showed the high hydrocarbon permeances. $\mathrm{C}_{3} \mathrm{H}_{6}$ permeance was $2.0 \times 10^{-6} \mathrm{~mol} \mathrm{~m}^{-2}$ $\mathrm{s}^{-1} \mathrm{~Pa}^{-1}$ with $\mathrm{C}_{3} \mathrm{H}_{6} / \mathrm{C}_{3} \mathrm{H}_{8}$ permeance ratio of 6.16 .

Key words : porous silica substrate $/$ MFI zeolite membrane / gas separation $/$ hydrocarbon separation

\section{1. 緒言}

ゼオライトは，その結晶細孔に起因する分子ふる い能や吸着性をもつことより, 多くの研究グループ により分離膜素材として検討されてきた。その中で

* Corresponding Author

Tel: 03-5859-8160

Fax: 03-5859-8160

E-mail: Lscathy@shibaura-it.ac.jp
も, MFIゼオライト膜は, テトラプロピルアンモニ ウムイオン存在下で比較的容易に合成されることも あり，非常に検討例が多い1 3)．1991年の MFIゼオ ライト膜の報告 ${ }^{1)}$ では，テフロン板上へMFI多結晶 の自立膜を作製していた。しかし，自立膜は機械的 強度が不足することが多く, その後の検討は, 多孔 質アルミナ基材を中心とした多孔質セラミックス基 材上への製膜が中心となっている．特に，近年では， 基材にMFIゼオライトの種結晶を塗布し，その後， 比較的希薄なアルカリゲル中で種結晶を成長させる 2 

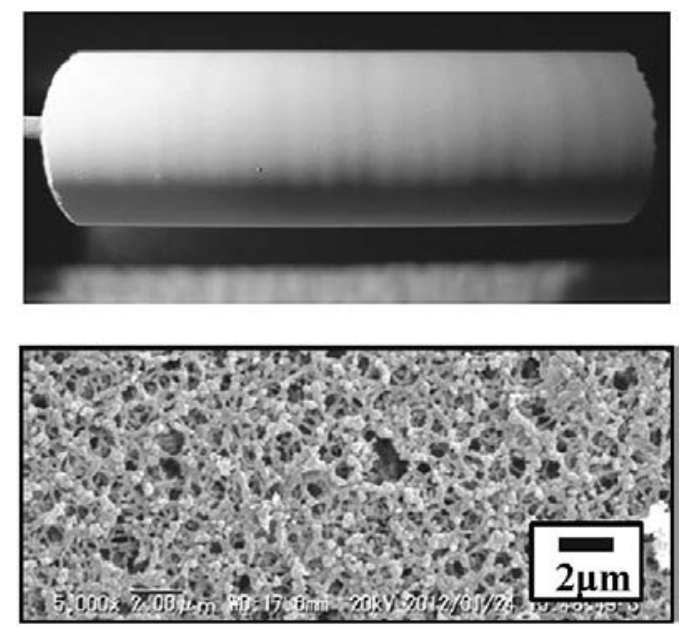

Fig. 1 Photograph (top) and surface SEM image (bottom) of the porous silica substrate.

次成長法 ${ }^{4 ）}$ と言われる合成法の報告例が多くなって きている. 2次成長法の製膜のポイントの一つは, 種 結晶の塗布である. Hasegawaら ${ }^{5)}$ は, 種結晶サイズ と種密度の検討を行い, 種結晶密度の影響が大きい ことを示した。本研究では, 多孔質セラミックス基 材としてシリカに注目した. シリカは, ゼオライト の原料成分の一つであることより, 合成ゲル中で溶 解し, 基材表面付近のみのシリカ濃度が変化する. そのため, 合成ゲルのシリカ濃度を下げることで, 基材表面近傍のみでゼオライト結晶が成長できる条 件を作り出せる.これより, 極薄膜のゼオライト層 が得られ，高い透過性をもつ膜が得られる可能性が

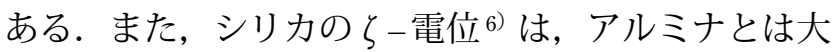
きく異なることより, 種結晶コーティング条件を検 討する必要がある. そこで, 本研究では, 多孔質シ リカ基材への MFIゼオライト膜の製膜条件を検討す ることで, 高い分離性能を示す膜の開発を目的とす る. 特に, 種結晶コーティング条件と結晶化時間な どに注目して検討を行った。

\section{2. 実験方法}

MFI種結晶およびMFIゼオライト膜の合成条件は, アルミナ基材へ製膜した既報7）をベースにして検討 を行った．種結晶となる MFIゼオライト粉末の合成 は水熱合成にて， $130^{\circ} \mathrm{C} ， 20$ 時間行った. 合成ゲルの 組成は, シリカ源としてコロイダルシリカ（日産化 学製: スノーテックス $\mathrm{S}$ ), 構造規定剤としてテトラ プロピルアンモニウムブロミド ( $\mathrm{TPABr}$ : アルドリ ッチ製）を用い, $\mathrm{SiO}_{2}: \mathrm{TPABr}: \mathrm{Na}_{2} \mathrm{O}: \mathrm{H}_{2} \mathrm{O}=1.0$ ： $0.25: 0.15: 40(\mathrm{~mol} / \mathrm{mol})$ とした. 多孔質セラミック ス基材として, 多孔質シリカ（住友電工製, 長さ 3

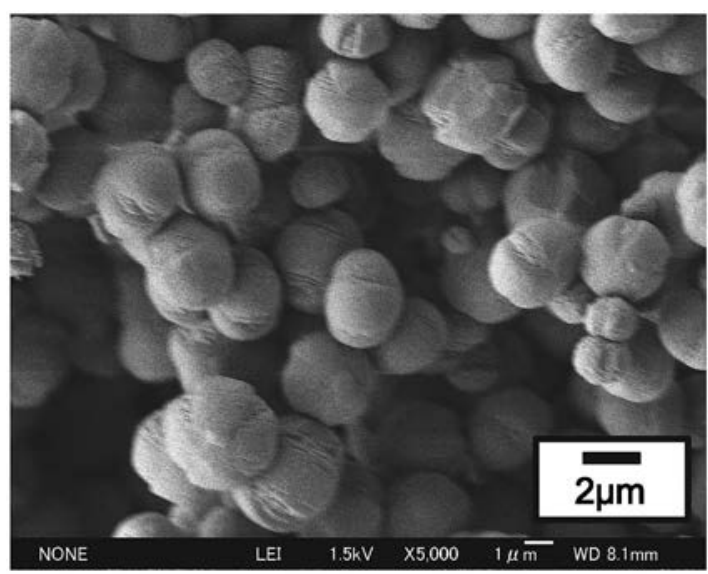

Fig. 2 SEM image of the MFI crystals for seeding.

$\mathrm{cm}$, 細孔径 $500 \mathrm{~nm}$, 膜厚 $1.5 \mathrm{~mm}$, 有効膜面積 6.28 $\mathrm{cm}^{2}$ ) もしくは多孔質 $\alpha$-アルミナ（ノリタケ製，長 さ $3 \mathrm{~cm}$, 細孔径 $700 \mathrm{~nm}$, 膜厚 $1.5 \mathrm{~mm}$, 有効膜面積 $6.28 \mathrm{~cm}^{2}$ ) を用いた. Fig. 1に多孔質シリカ基材の表 面写真と SEM 像を示す. SEM像より, 網目状の細孔 が存在していることがわかる．種結晶コーティング は, 上記の方法で作製した MFI粉末結晶を $0.5 \mathrm{~g} \mathrm{~L}^{-1}$ となるように分散液に導入した. 分散液の $\mathrm{pH}$ 調整は, 塩酸もしくは水酸化ナトリムを用い, 浸漬時間 $30 \mathrm{~s}$, 引き上げ速度 $0.5 \mathrm{~cm} \mathrm{~s}^{-1}$ とした. 製膜時のシリカ源に は，テトラメトキシシラン（信越化学製）を用い, 合成ゲルの組成は $\mathrm{SiO}_{2}: \mathrm{TPABr}: \mathrm{Na}_{2} \mathrm{O}: \mathrm{H}_{2} \mathrm{O}=1: 0.2$ : $0.04 \sim 0.666: 600(\mathrm{~mol} / \mathrm{mol})$ とした. MFIゼオラ イト膜の結晶化は, オートクレーブ中で $180^{\circ} \mathrm{C}, 4$ ～ 16 時間行った. その後, $500^{\circ} \mathrm{C}, 2$ 時間, 大気下で焼 成することで, 膜中の TPAイオンを除去した.

単成分透過試験用ガスには $\mathrm{N}_{2}, \mathrm{SF}_{6}, \mathrm{CH}_{4}, \mathrm{C}_{2} \mathrm{H}_{6}$, $\mathrm{C}_{3} \mathrm{H}_{6}, \mathrm{C}_{3} \mathrm{H}_{8}$ を用い, 室温にて圧力変化法により測定 した。供給側に常圧で各種単成分ガスを流通させ， 透過側を真空ポンプで減圧した. 真空ポンプを透過 側の系から遮断し, 透過側の圧力変化を測定するこ とで, 透過率を算出した. MFI種結晶およびMFIゼ オライト膜のキャラクタリゼーションは, X線回折装 置（XRD：リガク：RINT-TTR III）および電子顕微 鏡（SEM：日本電子：JSM7400F）を用いた。 また, MFI種結晶の $\zeta$-電位測定には, ナノ粒子解析装置 （堀場製作所：SZ-100Z）を用いた.

\section{3. 結果と考察}

\section{1 種結晶コーティング}

Fig. 2 に種結晶用の合成粉末のSEM 像を示す. 2 $3 \mu \mathrm{m}$ 程度の球状の結晶が確認できる. XRD 測定に より，この粉末は MFI構造をもっていることが確認 


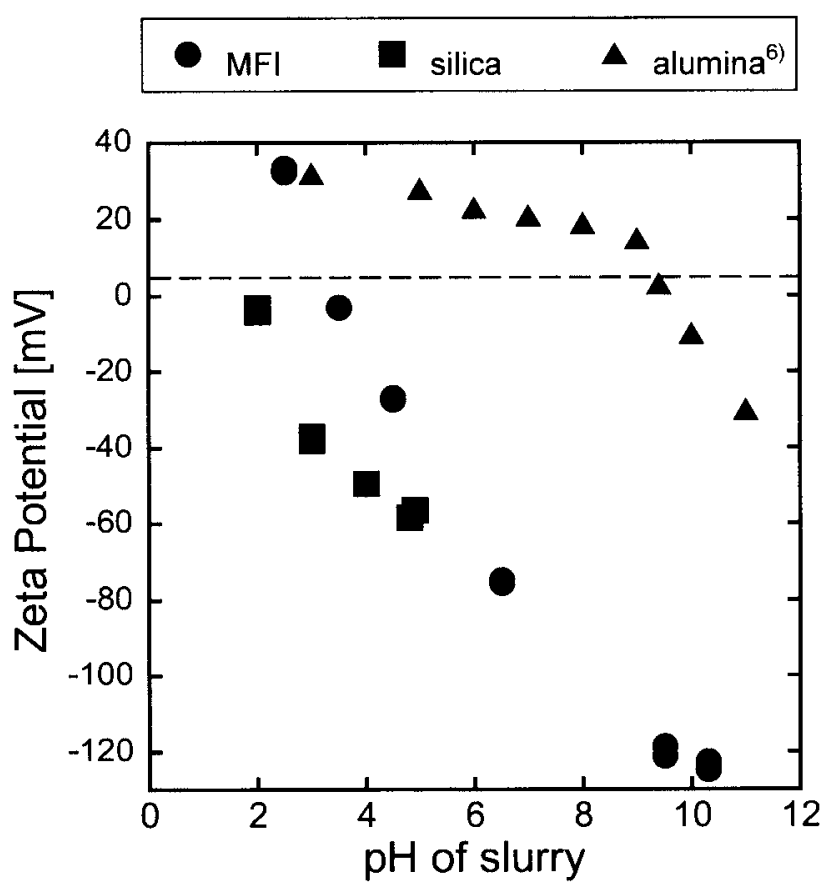

Fig. $3 \zeta$-potential measurements for MFI seed crystals and silica powders by changing $\mathrm{pH}$ of the slurry. ( $\zeta$-potential of alumina powders were also plotted based on the literature data ${ }^{6)}$ )

された. XRD 測定の半值幅よりシェラー式を用いて 粒子径を算出したところ，約 $500 \mathrm{~nm}$ となった。この ことから, SEM 像より観察された球状の結晶は, MFI結晶の凝集体であるといえる．以後，このMFI 結晶を製膜の種結晶として用いた.

MFI結晶を水中に分散させ $0.5 \mathrm{~g} \mathrm{~L}^{-1}$ となるように して, 多孔質基材へコーティングした. コーティン グを制御するためには, 分散液の $\mathrm{pH}$ が重要である.

Fig. 3 に, MFI種結晶, 多孔質シリカ基材を粉砕した 粉末の -電位の分散液 $\mathrm{pH}$ 依存性を示す。なお, 図 中にアルミナ粉末の -電位の報告值を記す ${ }^{6}$. 等電 点を示す $\mathrm{pH}$ は, MFI種結晶が約 3 , 多孔質シリカ基 材が約 2 , アルミナが約 9.5 であった. いずれの場合 も, 等電点より高い $\mathrm{pH}$ では, ら-電位がマイナスで あり, 等電点より低い $\mathrm{pH}$ では, ら-電位がプラスで ある．例えば, $\mathrm{pH}$ が約6である純水中では，MFI種 結晶はマイナス, 多孔質シリカ基材もマイナス, ア ルミはプラスとなる.

次に, 分散液の $\mathrm{pH}$ を 2 および 12 と制御した場合と, 純水を分散液とした 3 パターンの種結晶コーティング について検討を行った. Fig. 4に，基材として多孔質 シリカ基材, 多孔質アルミナ基材を用い, コーティ ング後の表面 SEM 像を示す。上段が多孔質シリカ基 材，下段が多孔質アルミナ基材の結果である. 左の SEM 像は分散液の $\mathrm{pH}$ を 2 とした場合, 中央の SEM

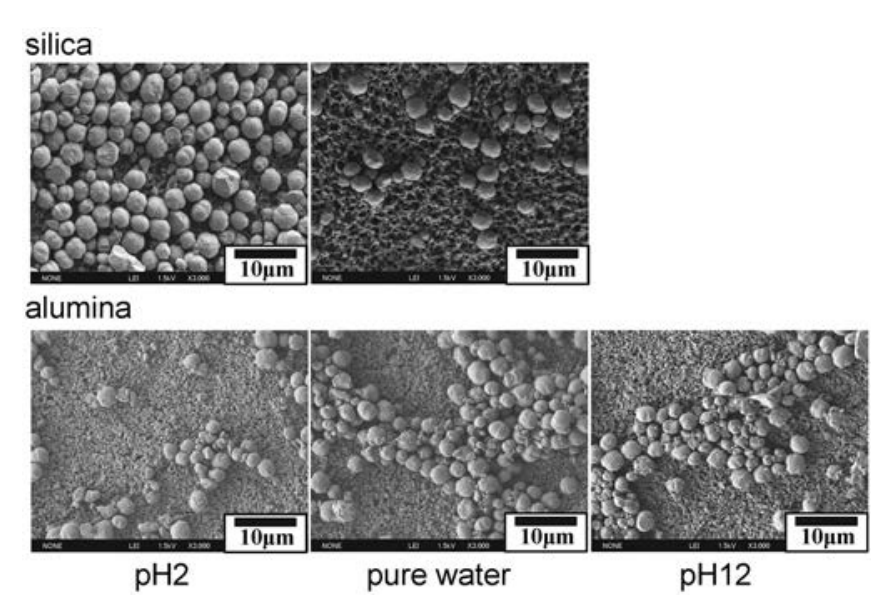

Fig. 4 Surface SEM images after seed slurry dipping on silica and alumina substrates.

像は純水を分散液とした場合, 右のSEM像は分散液 の $\mathrm{pH} 12$ にした場合の結果を示している. 左上の SEM 像より, 多孔質シリカ基材に $\mathrm{pH}$ 2でコーティン グした場合に，一面に MFI種結晶がコーティングさ れていることがわかる。一方, 純水でコーティング した場合の MFI種結晶の担持量は明らかに少ない. $\mathrm{pH} 2$ では, MFI種結晶はプラス, 多孔質シリカ基材 が中性付近となっている. 液中では MFI種結晶は, おのおのの荷電の反発力で分散でき, 分散液が比較 的安定となっている. 多孔質シリカ基材は中性なの で, MFI種結晶との反発力はなく, 均質な種結晶コ ーティングができたと考えられる．純水の場合は, 上記で記したとおり, MFI種結晶はマイナス, 多孔 質シリカ基材もマイナスとなっており, 基材と種結 晶の電子的な反発も影響したと思われる. 多孔質ア ルミナ基材では, 今回の条件では, すべて種結晶担 持量が小さかった. $\mathrm{pH} 2$ では, 基材, 種結晶いずれ もプラス, 純水では, 基材, 種結晶がプラスとマイ ナス, pH 12では，いずれもマイナスとなっている. 純水でのコーティング量が小さいことは, MFI種結 晶のスラリー中での分散性が影響した可能性がある. 以上より, 種結晶コーティングにてコーティング分 散液の $\mathrm{pH}$ は非常に重要であることが示された.

\subsection{MFIゼオライト膜結晶化条件の検討}

MFI種結晶コーティング後, 多孔質シリカ基材, 多孔質アルミナ基材への MFIゼオライト膜の結晶化 を行った. 結晶化前の多孔質シリカ基材と多孔質ア ルミナ基材の室温の $\mathrm{N}_{2}$ 透過率は，それぞれ， $8.2 \times$ $10^{-6} \mathrm{~mol} \mathrm{~m}^{-2} \mathrm{~s}^{-1} \mathrm{~Pa}^{-1}$ と $1.0 \times 10^{-5} \mathrm{~mol} \mathrm{~m}^{-2} \mathrm{~s}^{-1} \mathrm{~Pa}^{-1}$ であ つた. 今回用いた基材では, 多孔質アルミナ基材の 透過抵抗が小さかった. これらの基材に, 純水で MFI種結晶をコーティングし, $\mathrm{SiO}_{2}: \mathrm{TPABr}: \mathrm{Na}_{2} \mathrm{O}$ : 

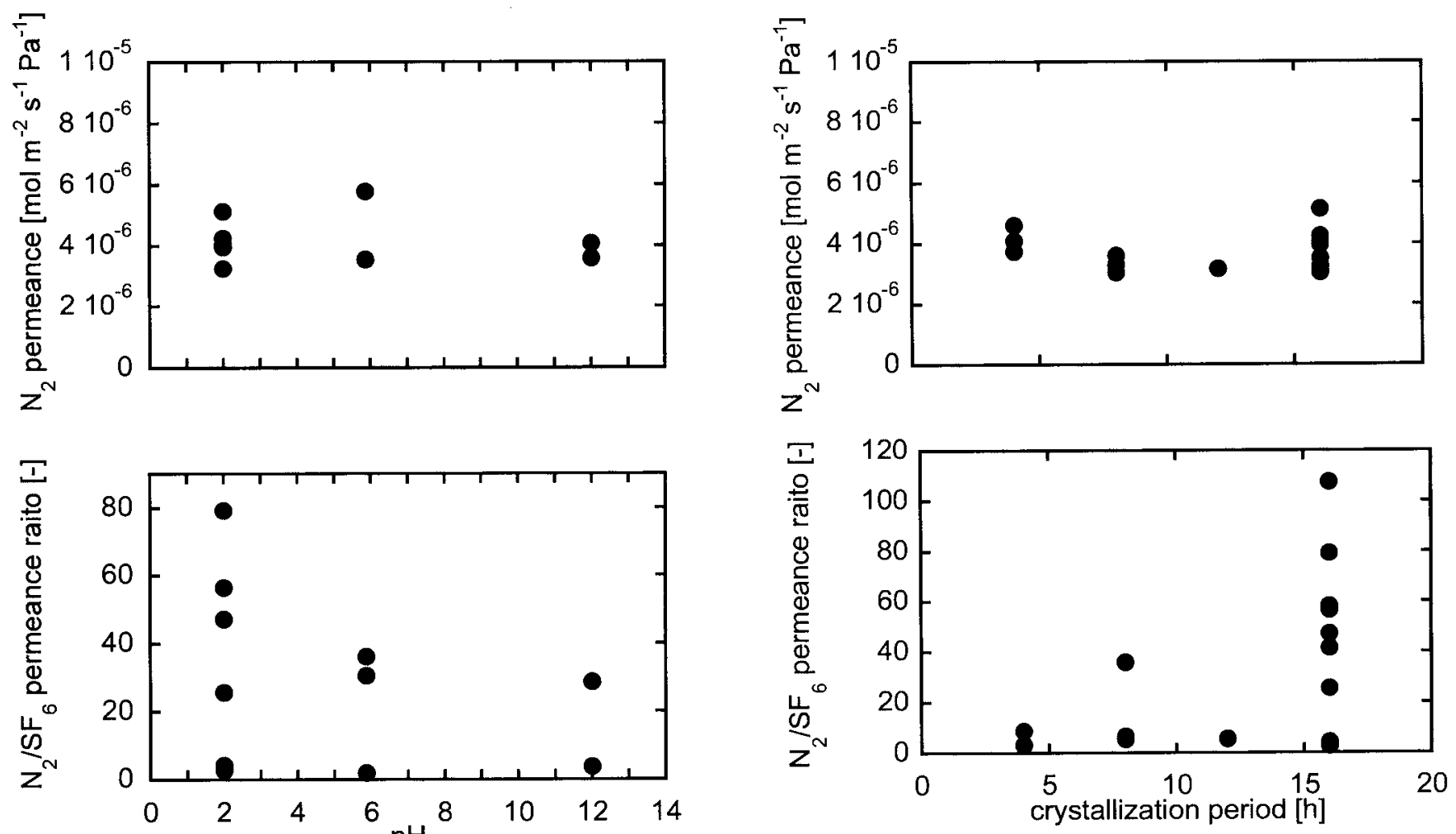

Fig. 5 Permeation properties through the membranes prepared by changing $\mathrm{pH}$ of the coating slurry.

$\mathrm{H}_{2} \mathrm{O}=1: 0.2: 0.04: 600(\mathrm{~mol} / \mathrm{mol})$ の合成ゲルで, 16 時間の結晶化を行った. XRD 測定にて，いずれの 基材上で得られた膜も MFI構造をもつことが示され た. 焼成後の $\mathrm{N}_{2}$ 透過率は, 多孔質シリカ基材が $3.6 \times 10^{-6} \mathrm{~mol} \mathrm{~m}^{-2} \mathrm{~s}^{-1} \mathrm{~Pa}^{-1}$, 多孔質アルミナ基材が 1.4 $\times 10^{-6} \mathrm{~mol} \mathrm{~m}^{-2} \mathrm{~s}^{-1} \mathrm{~Pa}^{-1}$ であった. $\mathrm{N}_{2} / \mathrm{SF}_{6}$ 透過率比は いずれの基材でも 30 以上であった. ベースとなる基 材の抵抗は多孔質アルミナ基材が小さいにもかかわ らず，製膜後は多孔質シリカ基材上の MFI膜の $\mathrm{N}_{2}$ 透 過率が大きくなった. $\mathrm{N}_{2}$ 透過率は, 基材とゼオライ 卜層の直列抵抗モデルで説明ができ，いずれの膜で も MFI結晶中の $\mathrm{N}_{2}$ 拡散係数が等しいと仮定する.こ の仮定を用いると, 多孔質シリカ基材と多孔質アル ミナ基材上へ製膜した MFIゼオライト膜の有効厚さ の比は 3.8 となる。詳細な議論には, MFI結晶中の $\mathrm{N}_{2}$ 拡散係数の評価や微細な膜構造の議論が必要であ るが, $\mathrm{N}_{2}$ 透過率が高いことより, 以後, 多孔質シリ カ基材の検討を行った.

多孔質シリカ基材の結晶化では，まず， $\mathrm{Na}_{2} \mathrm{O}$ 濃度 を検討した. MFI種結晶コーティング時の $\mathrm{pH}$ は 2 , 結晶化時間は 16 時間と固定した. シリカに対する原 料ゲルの $\mathrm{Na}_{2} \mathrm{O}$ 濃度を高くし $\mathrm{SiO}_{2}: \mathrm{TPABr}: \mathrm{Na}_{2} \mathrm{O}$ : $\mathrm{H}_{2} \mathrm{O}=1: 0.2: 0.167: 600(\mathrm{~mol} / \mathrm{mol})$ とした場合に, 得られた膜の $\mathrm{N}_{2} / \mathrm{SF}_{6}$ 透過率比は 13.7 と高くなかっ

Fig. 6 Permeation properties through the membranes prepared by changing crystallization periods.

た. また, $\mathrm{Na}_{2} \mathrm{O}$ 濃度を $\mathrm{SiO}_{2}: \mathrm{TPABr}: \mathrm{Na}_{2} \mathrm{O}: \mathrm{H}_{2} \mathrm{O}=$ $1: 0.2: 0.666: 600(\mathrm{~mol} / \mathrm{mol})$ と, さらに上昇させた 場合は, $\mathrm{N}_{2} / \mathrm{SF}_{6}$ 透過率比が 1.4 とクヌーセン拡散比 （2.2）より小さくなり, 分離性能が出現しなかった. この時, 多孔質シリカ基材が結晶化中に, 原料ゲル へ溶解した. 多孔質シリカ基材は, アルカリに溶解 することより, 高濃度 $\mathrm{Na}_{2} \mathrm{O}$ 中では製膜できないと思 われる. 以後, $\mathrm{Na}_{2} \mathrm{O}$ 濃度比は $\mathrm{SiO}_{2}: \mathrm{Na}_{2} \mathrm{O}=1: 0.04$ (mol/mol) と固定して検討した.

次に, MFI種結晶コーティング条件の検討を行っ た. 合成ゲル組成は $\mathrm{SiO}_{2}: \mathrm{TPABr}: \mathrm{Na}_{2} \mathrm{O}: \mathrm{H}_{2} \mathrm{O}=1$ : $0.2: 0.04: 600(\mathrm{~mol} / \mathrm{mol})$, 結晶化時間は 16 時間とし た. Fig. 5 に実験を行ったすべての膜の $\mathrm{N}_{2}$ 透過率お よび $\mathrm{N}_{2} / \mathrm{SF}_{6}$ 透過率比を示す. $\mathrm{N}_{2}$ 透過率は, コーティ ング条件によらず, $4 \times 10^{-6} \mathrm{~mol} \mathrm{~m}^{-2} \mathrm{~s}^{-1} \mathrm{~Pa}^{-1}$ 前後で, 大きな変化はなかった. 最も $\mathrm{N}_{2} / \mathrm{SF}_{6}$ 透過率比が高い 膜は $\mathrm{pH} 2$ でコーティングした膜で， 79.3 となった。 この時の $\mathrm{N}_{2}$ 透過率は $4.0 \times 10^{-6} \mathrm{~mol} \mathrm{~m}^{-2} \mathrm{~s}^{-1} \mathrm{~Pa}^{-1}$ であ った. 一方, 純水 $(\mathrm{pH} \mathrm{6)}$ もしくは $\mathrm{pH} 12$ でコーテ イングした膜は, $\mathrm{N}_{2} / \mathrm{SF}_{6}$ 透過率比は 40 未満となり, 高い選択性は見られなかった.この結果は, Fig. 4で 示した MFI種結晶コーティング後の SEM 像で示され たコーティング量とも対応している. また, 本研究 で検討した膜は, オートクレーブ中に 2 本もしくは 3 
Average thickness

$24 \mu \mathrm{m}$

Cross-sectional images

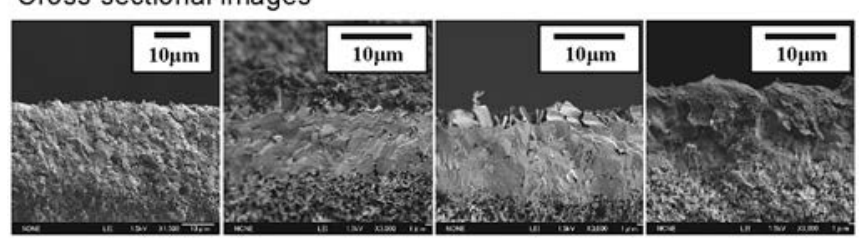

Surface images

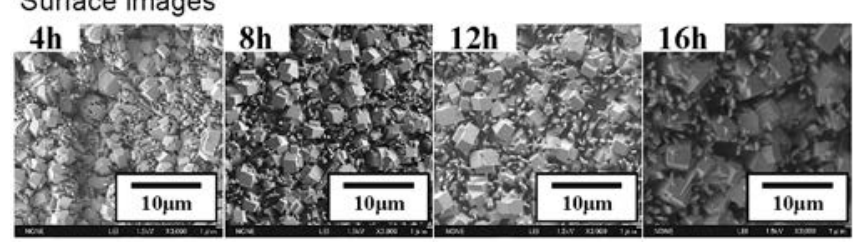

Fig. 7 SEM images of surface and cross-sectional images for the MFI membranes prepared by changing crystallization period. Average thicknesses of the MFI layers are also plotted in the figure.

本の基材を導入し結晶化を行っている. pH 2でコー ティングした膜の透過率比がばらついているが，同 時に合成した膜のいずれかは, $\mathrm{N}_{2} / \mathrm{SF}_{6}$ 透過率比が 40 以上となっていた，そのため，他の $\mathrm{pH}$ でコーティン グした膜とは有意な差があると言える. 以後, MFI 種結晶のコーティングは $\mathrm{pH} 2$ で行った。

最後に, 結晶化時間の検討を行った．合成ゲルの 組成を $\mathrm{SiO}_{2}: \mathrm{TPABr}: \mathrm{Na}_{2} \mathrm{O}: \mathrm{H}_{2} \mathrm{O}=1: 0.2: 0.04: 600$

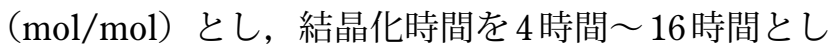
た, 得られた膜の透過性能を Fig. 6 に示す. $\mathrm{N}_{2}$ 透過 率は, 結晶化時間によらず, $4 \times 10^{-6} \mathrm{~mol} \mathrm{~m}^{-2} \mathrm{~s}^{-1} \mathrm{~Pa}^{-1}$ 前後で, 大きな変化はなかった。一方, 12 時間合成 の膜サンプルが少ないが, 概ね, 結晶化時間が長く なるに従い, $\mathrm{N}_{2} / \mathrm{SF}_{6}$ 透過率比は増加する傾向を示し たと言える. $\mathrm{N}_{2}$ 透過率変化が小さいことから考えて, 結晶化初期の 4 時間で大まかな結晶化は終わり，その 後は, $\mathrm{SF}_{6}$ 透過に関わる大きな結晶粒界の閉塞が進ん だと考えられる. そこで，Fig. 7 に結晶化時間が 4 時 間から 16 時間の膜の表面および断面の SEM 像を示 す. 図中に, 断面 SEM 像から観察した平均膜厚を示 す. 結晶化 4 時間で平均膜厚が $24 \mu \mathrm{m}$ で最も厚くな った. その後, 結晶化 8 時間で $11 \mu \mathrm{m}$ と半分くらい になり，12 時間後は $11 \mu \mathrm{m}, 16$ 時間後は $13 \mu \mathrm{m}$ とそ れほど大きな変化はなかった．結晶化 4 時間の表面 SEM 像を見ると, サイズが $2 \mu \mathrm{m}$ 程度の MFI結晶が ランダムに配列している. 結晶サイズは Fig. 2 で示し た MFI種結晶と同レベルであるが，結晶形態は異な っている. 種結晶は球状であり, ゼオライト微結晶 が凝集したように見えるが, 結晶化 4 時間の場合は, 角張った結晶構造が観察される。これより, 種結晶

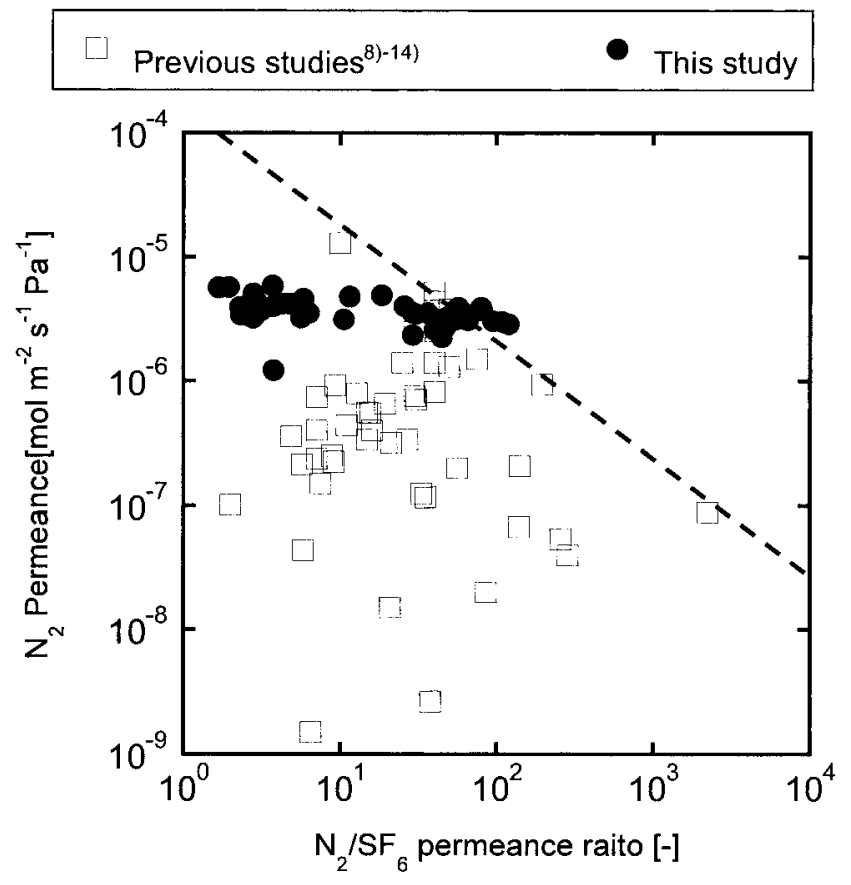

Fig. 8 Relationship between $\mathrm{N}_{2}$ permeance and $\mathrm{N}_{2} / \mathrm{SF}_{6}$ permeance ratio through MFI membranes.

が結晶化時に一度溶解して, その後, 結晶化して出 来た構造と考えられる. 結晶化 8 時間では, 平均膜厚 が半分以下になっている.この 4 時間の結晶化処理で は, 一度, 基材上へ堆積した MFI層が溶解したとい える. また, 結晶化 8 時間の SEM 像からは, $0.5 \mu \mathrm{m}$ 程度の MFI微結晶が多数観察される. MFI層の溶解 により, 膜面付近で 2 次核発生が起こり, 微結晶が作 製されたと推測できる．また，MFI結晶サイズも 3 $\mu \mathrm{m}$ 程度とわずかに大きくなった. 結晶化, 12 時間 と 16 時間では, メインとなる MFI結晶サイズが大き くなっている．結晶化時間 16 時間では, MFI結晶サ イズは約 $5 \mu \mathrm{m}$ である. 2次核発生によると思われる 微結晶サイズも, 結晶化時間に伴い大きくなってい る. 以上をまとめると, この膜の結晶化は 2 段階で進 行していると言える. まず, 初期の 4 時間で種結晶の 溶解による核発生が起こり, その後の 4 時間で, 結晶 化した MFI膜の溶解による 2 次核発生が起こる. そ の後は, 膜上の MFI結晶が少しずつ成長している. 合成ゲル中で核発生が支配的でない要因として, $\mathrm{SiO}_{2}: \mathrm{H}_{2} \mathrm{O}=1: 600(\mathrm{~mol} / \mathrm{mol})$ と, 比較的低いシリ 力濃度での結晶化を行っていることがあげられる. 最後の MFI結晶の成長に伴いピンホールが減少し, 高い $\mathrm{N}_{2} / \mathrm{SF}_{6}$ 透過率比を示す膜となる.

\section{3 ガス透過試験}

Fig. 8 に本研究で得られたすべての膜の $\mathrm{N}_{2} / \mathrm{SF}_{6}$ 透 過率比と $\mathrm{N}_{2}$ 透過率の関係を示す. 参考までに, 既 


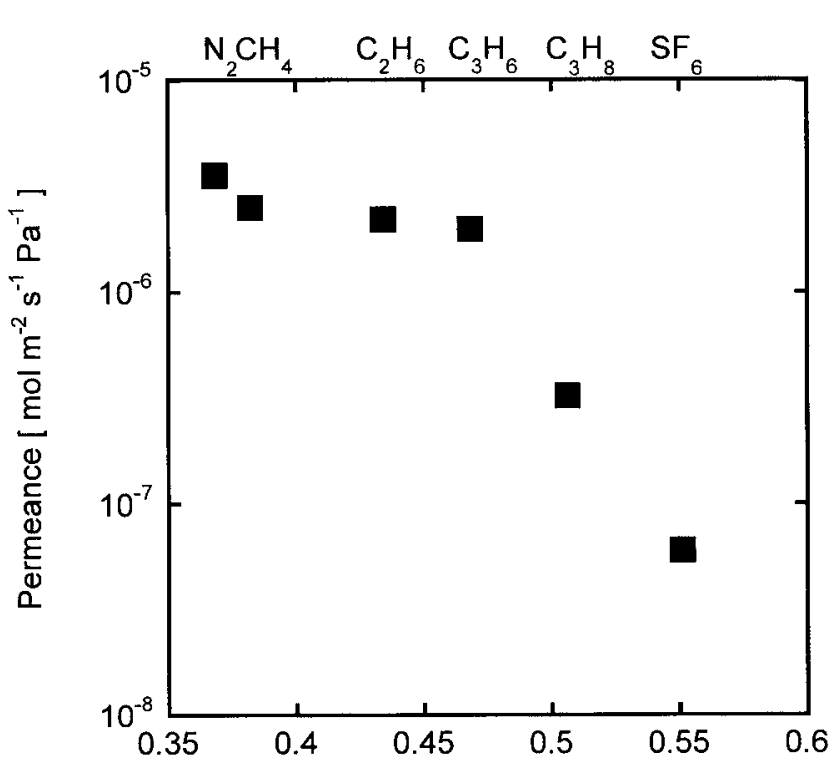

L-J length for the permeation molecules [ $\mathrm{nm}$ ]

Fig. 9 Single gas permeances for hydrocarbons.

報 ${ }^{8 \sim 14)}$ の MFI膜の透過性能も同じ図中に示した. 既 報の透過データもすべて室温 $\left(25^{\circ} \mathrm{C} \sim 30^{\circ} \mathrm{C}\right)$ での透 過試験結果である。本研究で得られた膜は, 既報の トレードオフラインを越える高い $\mathrm{N}_{2} / \mathrm{SF}_{6}$ 透過率比を 示すことがわかった．最も高い透過率比は 108 であっ た.この膜の $\mathrm{N}_{2}$ 透過率は, $3.0 \times 10^{-6} \mathrm{~mol} \mathrm{~m}^{-2} \mathrm{~s}^{-1} \mathrm{~Pa}^{-1}$ であった．今回調査を行った範囲で, $\mathrm{N}_{2} / \mathrm{SF}_{6}$ 透過率 比が 100 を越える膜として最も $\mathrm{N}_{2}$ 透過率が高い膜が 得られた. 結晶化前の多孔質シリカ基材の $\mathrm{N}_{2}$ 透過率 は, $8.2 \times 10^{-6} \mathrm{~mol} \mathrm{~m}^{-2} \mathrm{~s}^{-1} \mathrm{~Pa}^{-1}$ と今回製膜した膜の $\mathrm{N}_{2}$ 透過率とそれほど変わらない， $\mathrm{N}_{2}$ 透過率が減少せず に, 高い $\mathrm{N}_{2} / \mathrm{SF}_{6}$ 透過率比を示すことは, 分離層であ るMFI層が非常に薄いことを示唆している.

Fig. 9 に，この膜の単成分炭化水素透過試験結果を 示す. 縦軸に室温での各透過分子の透過率, 横軸に 透過分子の L-J 径を示す. MFIゼオライトの細孔径 より小さな分子である $\mathrm{CH}_{4}, \mathrm{C}_{2} \mathrm{H}_{6}, \mathrm{C}_{3} \mathrm{H}_{6}$ の透過率は, $2.5 \times 10^{-6} \mathrm{~mol} \mathrm{~m}^{-2} \mathrm{~s}^{-1} \mathrm{~Pa}^{-1}, 2.2 \times 10^{-6} \mathrm{~mol} \mathrm{~m}^{-2} \mathrm{~s}^{-1} \mathrm{~Pa}^{-1}$, $2.0 \times 10^{-6} \mathrm{~mol} \mathrm{~m}^{-2} \mathrm{~s}^{-1} \mathrm{~Pa}^{-1}$ と $\mathrm{N}_{2}$ 透過率と同レベルで あった． L-J 径が $5.1 \mathrm{~nm}$ である $\mathrm{C}_{3} \mathrm{H}_{8}$ の透過率は, $3.2 \times 10^{-7} \mathrm{~mol} \mathrm{~m}^{-2} \mathrm{~s}^{-1} \mathrm{~Pa}^{-1}$ と減少した. その結果, $\mathrm{C}_{3} \mathrm{H}_{6} / \mathrm{C}_{3} \mathrm{H}_{8}$ 透過率比は 6.2 となった. また, MFI細孔 である $0.53 \times 0.56 \mathrm{~nm}$ 付近の L-J 径を示す分子の透過 率が減少したことより, この膜の透過は, MFI細孔 に起因する分子ふるい機構と推測される.

\section{4. 結 言}

新規な多孔質シリカ基材にMFIゼオライト膜を製
膜した. pH 2でMFI種結晶コーティングすることで, 種結晶塗布量が最大になった。 $\mathrm{N}_{2} / \mathrm{SF}_{6}$ 透過率比は, 結晶化時間の増加と共に上昇する傾向を示し, 結晶 化時間 16 時間で 108 を示した。この時の $\mathrm{N}_{2}$ 透過率は $3.0 \times 10^{-6} \mathrm{~mol} \mathrm{~m}^{-2} \mathrm{~s}^{-1} \mathrm{~Pa}^{-1}$ となり, 今回調査した MFI ゼオライト膜としては, 最も高い性能を示したとい える. 炭化水素透過試験では, $\mathrm{C}_{3} \mathrm{H}_{6}$ の透過率 $2.0 \times$ $10^{-6} \mathrm{~mol} \mathrm{~m}^{-2} \mathrm{~s}^{-1} \mathrm{~Pa}^{-1}, \mathrm{C}_{3} \mathrm{H}_{6} / \mathrm{C}_{3} \mathrm{H}_{8}$ 透過率比 6.2 と高い 透過選択性を示した。

\section{文献}

1) Sano T, Kiyozumi $Y$, Kawamura M, Mizukami F, Takaya H, Mouri T, Inaoka W, Toida Y, Watanabe W, Toyoda K : Zeolites, 1 1, 842-845 (1991)

2) McLeary EE, Jansen JC, Kapteijn F : Micropor. Mesopor. Mater., 90, 198-220 (2006)

3) Yu M, Noble RD, Falconer JL: Acc. Chem. Res., 44, 11961206 (2011)

4) Xomeritakis G, Gouzinis A, Nair S, Okubo T, He M, Overney RM, Tsapatsis M : Chem. Eng. Sci., 54, 35213531 (1999)

5) Hasegawa $Y$, Ikeda T, Nagase T, Kiyozumi $Y$, Hanaoka T, Mizukami F : J. Membr. Sci., 280, 397-405 (2006)

6) Gunkoa VM, Zarkoa VI, Lebodab R, Chibowskic E : Adv. Colloid Interface Sci., 91, 1-112 (2001)

7) Zhou R, Zhu M, Chen X, Kita H : Chem. Lett., 39, 388-389 (2010)

8) Drobek M, Motuzas J, Loon M, Dirrix RWJ, Terpstra RA, Julbe A : J. Membr. Sci., 401-402, 144-151 (2012)

9) Tang Z, Kim SJ, Gu X, Dong J : Micropor. Mesopor. Mater., 1 18, 224-231 (2009)

10) Zhao Q, Wang J, Chu N, Yin X, Yang J, Kong C, Wang A, Lu J : J. Membr. Sci., 320, 303-309 (2008)

11) Çulfaz PZ, Çulfaz A, Kalıpçılar H : Micropor. Mesopor. Mater., 92, 134-144 (2006)

12) Au LTY, Chau JLH, Ariso CT, Yeung KL : J. Membr. Sci., 183,269-291 (2001)

13) Arruebo M, Coronas J, Menendez M, Santamaria J : Sep. Purif. Tech., 25, 275-286 (2001)

14) Kalıpçılar H, Çulfaz A : Micropor. Mesopor. Mater., 52, 3954 (2002)

(Received 24 February 2014; Accepted 8 April 2014) 